УДК: 33

DOI $10.21661 / \mathrm{r}-486286$

\title{
М.В. Бобылева
}

\section{РОЛЬ ВНУТРИКОРПОРАТИВНЫХ КОММУНИКАЦИЙ В СИСТЕМЕ УПРАВЛЕНИЯ ПЕРСОНАЛОМ ОРГАНИЗАЦИИ}

Аннотация: в работе рассмотрено влияние внутрикорпоративных коммуникаций на систему управления персоналом организации. Внутрикорпоративные коммуникаџии - один из множества важнейших факторов, напрямую влияющих на продуктивность и мотивачию людей в компании. Формирование и совершенствование системы внутрикорпоративных коммуникащий, правильное использование инструментов внутренних коммуникаций в деятельности по управлению персоналом компании позволяют добиться от сотрудников высокой эффективности и способствуют построению сильного HR-бренда.

Ключевые слова: внутрикорпоративные коммуникации, внутренние коммуникации, виды коммуникаций, инструменты внутрикорпоративных коммуникаичй, управление персоналом.

\section{M.V. Bobyleva}

\section{THE ROLE OF INTRACORPORATE COMMUNICATIONS IN THE PERSONNEL MANAGEMENT SYSTEM OF THE ORGANIZATION}

Abstract: the paper considers the influence of intracorporate communications on the organization's personnel management system. Internal corporate communications are one of the most important factors that directly affect the productivity and motivation in a company. The formation and improvement of the internal communications system and the correct usage of internal communication tools in the company's personnel management activities allow to achieve high efficiency and help build a strong HR brand.

Keywords: intracorporate communications, internal communications, types of communications, tools of intracorporate communications, personnel management. 
В настоящее время большинство руководителей понимает, что ключевой силой любого производства являются люди - сотрудники организации. Эффективность работников и их производительность напрямую зависит от множества факторов, в том числе от грамотно построенной системы управления персоналом на предприятиях. Построение эффективной системы внутрикорпоративных коммуникаций является одним из важнейших направлений деятельности по управлению персоналом, следовательно, коммуникации напрямую влияют на качество работы людей в компании. Учитывая тот факт, что в современном менеджменте вопросы построения системы внутрикорпоративных коммуникаций и ее использования в процессах управления персоналом слабо изучены, исследование влияния внутренних коммуникаций на систему управления персоналом особенно актуально.

Целью исследования является определение роли внутрикорпоративных коммуникаций в системе управления персоналом организации.

Коммуникации в организации необходимы для того, чтобы наладить связи между руководителями и исполнителями, выстроить их взаимодействие и обеспечить своевременный обмен необходимыми для работы данными без информационных потерь и помех.

На сегодняшний день выделяют [2, с. 63] следующие виды внутренних коммуникаций:

1. Горизонтальные - коммуникации лиц, равных по положению;

2. Вертикальные - коммуникации между руководителями и подчиненными.

Вертикальные коммуникации делятся [2, с. 64] на:

1. Восходящие - коммуникации, идущие от сотрудника к руководителю («оповещение» менеджеров о действиях исполнителей);

2. Нисходящие - коммуникации, идущие от руководителя к сотруднику (информирование работников о решениях руководства, приказы, распоряжения).

Для эффективной работы сотрудников любого предприятия важно совершенствовать все перечисленные виды коммуникаций, поскольку именно это позволит повысить лояльность персонала к руководству и организации в целом, 
укрепить корпоративную культуру, создать благоприятный микроклимат в коллективе, снизить текучесть кадров, а также преодолеть коммуникационные барьеры, мешающие выполнять работу оперативно и точно.

Любая современная организация стремится к созданию уникального HRбренда, который позволит привлекать новых талантливых профессионалов и улучшит имидж компании на рынке, в том числе в глазах партнеров и клиентов. Для формирования мощного HR-бренда любому работодателю важно развивать корпоративную культуру, что невозможно сделать без использования инструментов внутрикорпоративных коммуникаций [3, с. 93]. Посредством информационных стендов, внутренних электронных рассылок, порталов и корпоративных мероприятий можно транслировать сотрудникам ценности организации, формировать приверженность людей к месту, где они работают, обеспечивая их необходимой информацией о жизни компании и деятельности руководителей.

Стоит отметить, что развитие системы внутренних коммуникаций в компании существенно улучшает микроклимат в коллективах: постоянная информированность сотрудников о текущей ситуации снижает уровень тревожности, уменьшает число конфликтов, сокращает количество оснований для распространения слухов. Обеспечить информированность можно путем создания корпоративных печатных изданий, новостных порталов, корпоративного телевидения и непосредственного общения руководителей и подчиненных на планерках, совещаниях, личных приемах.

Кроме того, для уменьшения издержек на адаптацию и обучение персонала, повышения его эффективности, одним из направлений кадровой политики компаний становится снижение текучести кадров. Установлено [1, с. 12], что зачастую текучесть кадров обусловлена безразличным отношением руководства к подчиненным, плохими отношениями в коллективе, низким уровнем информированности людей в рабочих вопросах, и, как следствие, неудовлетворительными результатами, конфликтами с руководством, снижением мотивации. Внутрикорпоративные коммуникации призваны обеспечить информированность работников для эффективного выполнения ими трудовых функций, укреплению 
отношений между подчиненными и их руководителями. Использование аналитических инструментов внутрикорпоративных коммуникаций, а именно различных социологических исследований (опросов, мониторингов, фокус-групп, наблюдений), внедрение горячей линии позволит сотрудникам дать работодателю обратную связь, позволит установить причины частых увольнений и устранить их.

Отдельно стоит рассмотреть вопрос получения обратной связи в компании. Любому сотруднику важно чувствовать себя частью организации, испытывать гордость за результаты своей работы и быть причастным к делам компании. Именно поэтому важно налаживать горизонтальные нисходящие коммуникации: руководителю необходимо давать обратную связь своим подчиненным посредством личного общения, проведения собраний, объявления благодарностей или размещения информации о людях на доске почета. Также многие руководители часто не уделяют внимания получению обратной связи от подчиненных, что является ошибкой: прислушиваясь к сотрудникам и получая их мнения по актуальным вопросам можно упростить процесс принятия управленческих решений, разрешить острые для компании проблемы и повысить лояльность людей, формируя у них чувство приверженности и благодарности за возможность участвовать в жизни предприятия.

Таким образом, можно сделать вывод о том, что внутрикорпоративные коммуникации играют важную роль в системе управления персоналом организации. Формирование и развитие системы внутренних коммуникаций позволяет решить актуальные для компании проблемы и достичь поставленных целей в области кадровой политики. Используя такие инструменты внутренних коммуникаций как корпоративные издания и порталы, мероприятия для сотрудников, исследования и горячие линии, личное общение с подчиненными можно повысить лояльность людей к руководству, сформировать приверженность, снизить текучесть кадров, тем самым создавая сильный HR-бренд, обеспечивающий компании стабильность и успех. 


\section{Список литературы}

1. Каймакова М.В. Анализ использования человеческих ресурсов. - Ульяновск: УлГТУ, 2011. - 80 с.

2. Кверк Б. Создавая связи. Внутрикорпоративные коммуникации в бизнесстратегии. - М.: Вершина, 2012. - 416 с.

3. Минаева Л.В. Внутрикорпоративные связи с общественностью. Теория и практика. - М.: Аспект Пресс, 2010. - 287 с.

\section{References}

1. Kaimakova, M. V. (2011). Analiz ispol'zovaniia chelovecheskikh resursov., 80. Ul'ianovsk: UlGTU.

2. Kverk, B. (2012). Sozdavaia sviazi. Vnutrikorporativnye kommunikatsii v biznes-strategii., 416. M.: Vershina.

3. Minaeva, L. V. (2010). Vnutrikorporativnye sviazi s obshchestvennost'iu. Teoriia i praktika., 287. M.: Aspekt Press.

Бобылева Мария Вадимовна - бакалавр, магистрант, ФГБОУ ВПО «СанктПетербургский национальный исследовательский университет информационных технологий, механики и оптики», Россия, Санкт-Петербург.

Bobyleva Mariia Vadimovna - graduate student at the FSAEI of HE «St. Petersburg National Research University of Informational Technologies, Mechanics and Optics», Russia, Saint-Petersburg. 